\title{
KORUPSI DI SEKTOR SWASTA DAN TANGGUNG JAWAB PIDANA KORPORASI ${ }^{1}$
}

\author{
Eddy O. S. Hiariej \\ Fakultas Hukum Universitas Gadjah Mada \\ Jl. Sosio Yustisia No. 1, Bulaksumur, Kab. Sleman, D.I. Yogyakarta 55281 \\ eddyosh@yahoo.com
}

\begin{abstract}
Corruption in Indonesia continue to spread through all aspects of societal life, giving more urgency to engance the existing legal instrumnets to overcome such crime. Having ratified the UN Convention on Anti-Corruption, there is growing need to re-adjust Indonesian national law to ensure its fullcompliance to the Convention. One of the aspects that is currently lacking from Indonesia's national law on anti-corruption is corruption committed within the private sector, that does not only subjectify individual as the offender, but legal entity as well. The research methodology used in this article is literature review as well as analyzing theories relevant to corporate criminal responbility. This article will also compare the concept of corporation from several countries.
\end{abstract}

Keywords: Corruption; Corporation; Criminal Responbility

\begin{abstract}
Abstrak
Korupsi di Indonesia hampir merata di seluruh aspek kehidupan sehingga membutuhkan instrumen hukum yang memadai untuk menanggulanginya. Selain Konvensi PBB mengenai antikorupsi yang telah diratifikasi, penyesuaian hukum nasional dengan konvensi tersebut sangatlah mendesak. Salah satu hal baru yang belum ada dalam undang-undang nasional kita adalah mengenai korupsi di sektor swasta yang tidak hanya melibatkan individu sebagai pelaku korupsi, namun juga melibatkan badan hukum sebagai pelaku. Metode penelitian dalam tulisan ini seluruhnya menggunakan studi pustaka. Selain menganalisis teori-teori yang aktual terkait pertanggungjawaban pidana korporasi, tulisan ini juga mengulas mengenai pertanggungjawaban korporasi di beberapa negara.
\end{abstract}

Kata Kunci: Korupsi; Korporasi; Pertanggungjawaban Pidana

\footnotetext{
${ }^{1}$ Artikel hasil penelitian mandiri yang dilakukan penulis pada tahun 2019.
} 


\section{A. Pendahuluan}

Tindak pidana korupsi di Indonesia sudah dianggap berada dalam lingkaran setan. Lingkaran setan atau vicious circle diartikan sebagai perangkap dimana negaranegara selalu terkena dampak negatif dalam berbagai kondisi (Emmanuel, 2019). Hal ini dapat dilihat bahwa angka korupsi yang tinggi biasanya berkaitan dengan negara yang miskin atau pembangunannya terhambat yang dalam dunia ekonomi dikenal dengan teori modernisasi yang membahas hambatan-hambatan pembangunan ekonomi negara-negara. Dimana penyebab utama dari keterbelakangan ekonomi tersebut adalah tindak pidana korupsi (Emmanuel, 2019).

Kamis 11 Oktober 2018, untuk pertama kalinya Komisi Pemberantasan Korupsi (KPK) mendakwa korporasi sebagai pelaku korupsi. Dalam sidang perdana, KPK mendakwa PT. Duta Graha Indah yang telah berganti nama menjadi PT Nusantara Konstruksi Enjiniring yang diwakili Djoko Eko Suprastowo sebagai Direktur Utama. Bahkan saat ini, KPK mencoba membidik korporasi yang acapkali melakukan penyuapan terhadap penyelenggara negara.

Pemerintah Indonesia telah meratifikasi United Nations Convention Against Corruption (UNCAC) dengan UndangUndang Nomor 7 Tahun 2006. Berdasarkan konvensi tersebut, ada beberapa perbuatan yang dikriminalisasikan dan dianggap memenuhi kualifikasi tindak pidana korupsi. Berdasarkan Background Paper Declaration of 8 International Conference Against Corruptiondi yang diselenggarakan di Lima, Peru (7-11 September 1997), ada enam dampak korupsi yang melatarbelakangi internasionalisasi kejahatan korupsi. Pertama, korupsi dianggap merusak demokrasi. Kedua, korupsi dianggap merusak aturan hukum. Ketiga, korupsi dapat mengganggu pembangunan berkelanjutan. Dampak yang keempat dari korupsi adalah merusak pasar. Kelima, korupsi dapat merusak kualitas hidup, sebab jika tidak dikorup, anggaran negara dapat digunakan untuk membiayai pendidikan dan pelayanan kesehatan masyarakat secara memadai. Dampak yang keenam atau yang terakhir, korupsi dianggap melanggar hakhak asasi manusia. Hal ini berkaitan dengan hak-hak atas kehidupan yang layak bagi masyarakat namun terabaikan karena negara tidak memiliki cukup anggaran untuk meningkatkan kesejahteraan rakyat akibat korupsi (Mochtar, 2018).

Berdasarkan keenam dampak korupsi tersebut, adapun tujuan UNCAC sebagaimana Penjelasan United Nations Convention Against Corruption adalah sebagai berikut: Pertama, mencegah dan membasmi korupsi secara efisien dan efektif. Oleh karena itu, harus ada koordinasi di antara institusi-institusi pemberantasan korupsi termasuk jaminan dan perlindungan terhadap masyarakat yang melaporkan adanya dugaan korupsi. Kedua, kerjasama internasional dan bantuan teknis termasuk pengembalian aset kejahatan. Kerjasama di sini tidak hanya di antara negara peserta konvensi, namun kerjasama juga dilakukan dengan negara-negara yang bukan merupakan state party dari konvensi tersebut. Ketiga, integritas, akuntabilitas dan transparansi serta manajemen yang tepat di sektor publik.

Tidak seperti konvensi lainnya yang merumuskan unsur-unsur suatu kejahatan atau definisi mengenai suatu kejahatan, UNCAC tidak mendefinisikan apa yang dimaksud dengan korupsi. Akan tetapi, dalam Bab III UNCAC terkait kriminalisasi dan penegakan hukum, terdapat 11 dalam perbuatan yang dikriminalisasikan sebagai korupsi. Salah satu perbuatan yang dikriminalisasi dalam konvensi tersebut adalah korupsi di sektor swasta. Penuntutan terhadap korporasi sebagai subjek hukum tindak pidana korupsi adalah hal yang langka di Indonesia, kendatipun instrumen hukumnya telah ada sejak tahun 1999. Di satu sisi, pertanggungjawaban korporasi telah diatur dalam undang-undang pemberantasan tindak pidana korupsi, namun di sisi lain korupsi di sektor swasta merupakan hal baru dalam Konvensi PBB. 
Dalam tulisan ini teori-teori yang digunakan sebagai pisau analis dalam pembahasan adalah teori-teori mengenai kejahatan korupsi dan pertanggungjawaban korporasi. Landasan teori ini sekaligus juga menunjukkan state of the art dan berikutnya akan menegaskan kebaruan dari pembahasan dalam tulisan ini. Mengenai teori tentang kejahatan korupsi, pengertian korupsi dapat dilihat dari dua perspektif. Pertama, korupsi dalam perspektif studi kejahatan, sedangkan kedua, korupsi dalam perspektif hukum pidana.

Dalam studi kejahatan korupsi sangatlah luas dan meliputi beberapa tipe. Paling tidak ada sembilan tipe korupsi dalam studi kejahatan. Pertama, political bribery adalah termasuk kekuasaan di bidang legislatif sebagai badan pembentuk undang-undang. Secara politis badan tersebut dikendalikan oleh suatu kepentingan karena dana yang dikeluarkan pada masa pemilihan umum sering berkaitan dengan aktivitas perusahaan tertentu. Para pengusaha berharap anggota yang duduk di parlemen dapat membuat aturan yang menguntungkan mereka. Kedua, political kickbacks, yaitu kegiatan-kegiatan yang berkaitan dengan sistem kontrak pekerjaan borongan antara pejabat pelaksana dan pengusaha yang memberi peluang untuk mendatangkan banyak uang bagi pihakpihak yang bersangkutan. Ketiga, election fraud adalah korupsi yang berkaitan langsung dengan kecurangan pemilihan umum. Keempat, corrupt campaign practice adalah praktek kampanye dengan menggunakan fasilitas negara maupun uang negara oleh calon yang sedang memegang kekuasaan negara (Beirne, 1995). Kelima, discretionery corruption yaitu korupsi yang dilakukan karena ada kebebasan dalam menentukan kebijakan.

Keenam, illegal corruption yakni korupsi yang dilakukan dengan mengacaukan bahasa hukum atau interpretasi hukum. Tipe korupsi ini rentan dilakukan oleh aparat penegak hukum, baik itu polisi, jaksa, pengacara, maupun hakim. Ketujuh, ideological corruption ialah perpaduan antara discretionery corruption dan illegal corruption yang dilakukan untuk tujuan kelompok. Kedelapan, political corruption adalah penyelewengan kekuasaan atau kewenangan yang dipercayakan kepadanya untuk mendapatkan keuntungan pribadi atau kelompok yang berkaitan dengan kekuasaan. Kesembilan, mercenary corruption yaitu menyalahgunakan kekuasaan semata-mata untuk kepentingan pribadi (Isra, 2009).

Rousseau menyatakan bahwa pihakpihak yang mendapatkan kewenangan mengorganisasi kepentingan publik adalah pemerintah. Namun, kewenangan tersebut tidak selalu dijalankan sebagaimana mestinya, sehingga jika terjadi penyalahgunaan, maka korupsi timbul. Ketika kewenangan disalahgunakan untuk kepentingan pribadi, biasa dikenal dengan korupsi (Liu, 2016). Namun, tindak pidana korupsi semakin berkembang definisinya. Menurut Z.K. He, Korupsi meliputi pelaku, motivasi tindakannya, modus operandinya, dan dampak negatifnya (He Zengke, 2003).

Korupsi dalam perspektif hukum pidana tidaklah terlepas dari rumusan delik. Artinya, perbuatan apa saja yang dikualifikasikan sebagai tindak pidana korupsi haruslah mengacu pada undangundang pemberantasan tindak pidana korupsi dan Konvensi PBB mengenai antikorupsi. Tulisan singkat ini akan menggunakan perspektif hukum pidana dalam membahas korupsi yang akan diuraikan lebih lanjut dalam analisis dan pembahasan tulisan ini.

Selanjutnya mengenai teori pertanggungjawaban Korporasi, dalam doktrin hukum pidana, paling tidak kita mengenal ada 5 teori pertanggungjawaban korporasi. Pertama, teori identifikasi yang menyatakan bahwa suatu korporasi dapat melakukan kejahatan melalui individu yang bertindak untuk dan atas nama korporasi yang memiliki posisi tinggi atau memainkan suatu fungsi kunci dalam pengambilan keputusan korporasi. Teori ini juga disebut sebagai alter ego (Pinto, 2003). Kedua, vicarious liability yang menyatakan bahwa seseorang dapat bertanggung jawab atas 
perbuatan pidana yang dilakukan oleh orang lain. Dalam konteks korporasi, pertanggungjawaban pidana dibebankan kepada pengurus korporasi sebagai 'agen' dari korporasi tersebut (Muladi dan Diah Sulistyani RS, 2015). Vicarious liability atau pertanggungjawaban pengganti pada awalnya diterapkan dalam kejahatan terhadap lingkungan. Perkembangan lebih lanjut dari vicarious liability, ada yang dikenal dengan absolut liability dan strict liability. Perbedaan prinsip keduanya: dalam absolut liability tidak diperlukan adanya kesalahan atau mens rea, namun yang dibutuhkan adalah pembuktian bahwa telah terjadi suatu tindak pidana. Sedangkan dalam strict liability mensyaratkan pembuktian bahwa terdakwa melakukan perbuatan yang diragukan. Artinya, terdakwa berhak untuk dilakukan due diligence berkaitan dengan kasus tersebut.

Ketiga, teori delegasi yang menyatakan bahwa pertanggungjawaban pidana diletakkan kepada orang yang oleh direksi diberi delegasi untuk melaksanakan kewenangan korporasi. Teori ini sebagai jalan tengah antara teori identifikasi yang sempit dan teori vicarious liability yang terlalu luas manakala berhadapan dengan struktur korporasi yang rumit. Keempat, teori agregasi yang menyatakan bahwa pertanggungjawaban pidana dapat dibebankan kepada korporasi jika perbuatan tersebut dilakukan sejumlah orang yang memenuhi unsur delik yang mana antara satu dengan yang lain saling terkait dan tidak berdiri sendiri. Kelima, teori model budaya kerja yang menyatakan bahwa kebijakan korporasi yang tersurat dan tersirat memengaruhi cara kerja korporasi dan dapat dimintakan pertanggungjawaban jika tindakan seseorang memiliki dasar rasional bahwa korporasi memberikan wewenang atau mengizinkan perbuatan tersebut (Muladi dan Diah Sulistyani RS, 2015).

Berdasarkan uraian latar belakang yang telah penulis paparkan, ada dua permasalahan hukum yang akan penulis bahas dalam tulisan ini yaitu: Pertama, bagaimana pengaturan korupsi sektor swasta di masa mendatang? Kedua, bagaimana pertanggungjawaban pidana korupsi yang dilakukan oleh korporasi?

\section{B. Metode Penelitian}

Tulisan ini sepenuhnya berdasarkan studi pustaka terhadap berbagai bahan hukum. Adapun bahan hukum yang digunakan adalah bahan hukum primer berupa sejumlah undang-undang dan bahan hukum tertier. Semua bahan hukum tersebut dianalisis dengan berbagai doktrin, teori, dan asas hukum secara konseptual.

\section{Hasil dan Pembahasan}

\section{Korupsi di Sektor Swasta}

Dalam konvensi PBB mengenai antikorupsi terdapat kriminalisasi terhadap sejumlah perbuatan. Secara garis besar, ada sebelas perbuatan: Pertama, bribery of national public officials atau penyuapan pejabat-pejabat publik nasional (Pasal 15 United Nations Convention Against Corruption). Inti dari tindakan tersebut adalah janji, menawarkan atau memberikan kepada seorang pejabat publik, secara langsung atau tidak langsung suatu keuntungan yang layak untuk pejabat itu sendiri atau untuk orang lain atau badan hukum, agar pejabat itu bertindak atau menahan diri dari melakukan suatu tindakan dalam melaksanakan tugas resminya. Demikian pula tindakan permohonan atau penerimaan oleh seorang pejabat publik, secara langsung atau tidak langsung suatu keuntungan yang layak untuk pejabat itu sendiri atau untuk orang lain atau badan hukum, agar pejabat itu bertindak atau menahan diri dari melakukan suatu tindakan dalam melaksanakan tugas resminya.

Kedua, bribery of foreign public officials and officials of public international organizations atau penyuapan pejabatpejabat publik asing dan pejabat-pejabat dari organisasi-organisasi internasional publik (Pasal 15 United Nations Convention Against Corruption). Tindakan-tindakan tersebut meliputi dengan sengaja 
menjanjikan, menawarkan atau memberikan kepada seorang pejabat publik asing atau seorang pejabat dari suatu organisasi internasional publik, secara langsung atau tidak langsung suatu keuntungan yang layak untuk pejabat itu sendiri atau untuk orang lain atau badan hukum, agar pejabat itu bertindak atau menahan diri dari melakukan suatu tindakan dalam melaksanakan tugas resminya, guna memperoleh atau mempertahankan bisnis atau keuntungan lain yang tidak layak berkaitan dengan perilaku bisnis internasional. Demikian pula tindakan-tindakan yang meliputi sengaja memohon atau menerima oleh seorang pejabat publik asing atau seorang pejabat dari suatu organisasi internasional publik, secara langsung atau tidak langsung suatu keuntungan yang layak untuk pejabat itu sendiri atau untuk orang lain atau badan hukum, agar pejabat itu bertindak atau menahan diri dari melakukan suatu tindakan dalam melaksanakan tugas resminya.

Ketiga, embezzlement, misappropriation or other diversion of property by a public official atau penggelapan, penyelewengan atau pengalihan kekayaan dengan cara lain oleh pejabat publik (Pasal 17 United Nations Convention Against Corruption). Tindakan tersebut adalah menggelapkan, menyelewengkan atau mengalihkan dengan cara lain oleh pejabat publik untuk keuntungan dirinya sendiri atau untuk keuntungan orang lain atau badan lain, kekayaan, dana-dana publik atau perorangan atau sekuritas atau segala sesuatu yang bernilai yang dipercayakan kepada pejabat publik itu berdasarkan kedudukannya.

Keempat, trading in influence atau memperdagangkan pengaruh (Pasal 18 United Nations Convention Against Corruption). Kualifikasi tindakan tersebut adalah dengan sengaja menjanjikan, menawarkan atau memberikan kepada seorang pejabat publik atau orang lain, secara langsung atau tidak langsung, suatu keuntungan yang tidak semestinya, agar pejabat publik atau orang itu menyalahgunakan pengaruhnya yang nyata atau yang diperkirakan dengan maksud untuk memperoleh otoritas administrasi atau otoritas publik dari negara, suatu keuntungan yang tidak semestinya. Demikian pula tindakan memohon atau menerima dari pejabat publik atau orang lain secara langsung atau tidak langsung, suatu keuntungan yang tidak semestinya, agar pejabat publik atau orang itu menyalahgunakan pengaruhnya yang nyata atau yang diperkirakan dengan maksud untuk memperoleh otoritas administrasi atau otoritas publik dari negara, suatu keuntungan yang tidak semestinya.

Kelima, abuse of function atau penyalahgunaan fungsi (Pasal 19 United Nations Convention Against Corruption). Kualifikasi tindakan tersebut adalah dengan sengaja menyalahgunakan fungsi atau kedudukan dengan melakukan atau tidak melakukan suatu tindakan secara melawan hukum oleh seorang pejabat publik dalam melaksanakan fungsinya dengan maksud untuk memperoleh suatu keuntungan yang tidak semestinya untuk dirinya sediri atau untuk orang lain atau badan lain.

Keenam, illicit enrichment atau memperkaya secara tidak sah yaitu dengan sengaja memperkaya secara tidak sah berupa suatu kenaikan yang berarti dari aset-aset seorang pejabat publik yang tidak dapat dijelaskan secara masuk akal berkaitan dengan pendapatannya yang sah (Pasal 20 United Nations Convention Against Corruption).

Ketujuh, bribery in the private sector atau penyuapan di sektor swasta berupa tindakan yang menjanjikan, menawarkan atau memberikan secara langsung atau tidak langsung suatu keuntungan yang tidak semestinya kepada seseorang yang memimpin atau bekerja dalam suatu kapasitas untuk suatu badan di sektor swasta, untuk dirinya sendiri atau orang lain, agar ia dengan melanggar tugas-tugasnya, melakukan sesuatu atau menahan diri dari melakukan suatu tindakan. Demikian pula tindakan berupa memohon atau menerima secara langsung atau tidak langsung suatu keuntungan yang tidak semestinya yang dilakukan oleh seseorang yang memimpin 
atau bekerja dalam suatu kapasitas apapun untuk suatu badan sektor swasta, untuk dirinya sendiri atau orang lain, agar ia secara melawan hak, melakukan sesuatu atau menahan diri untuk melakukan sesuatu (Pasal 21 United Nations Convention Against Corruption).

Kedelapan, emblezzement of property in the private sector atau penggelapan kekayaan dalam sektor swasta yaitu tindakan dengan sengaja dalam menjalankan kegiatan-kegiatan ekonomi, keuangan atau perdagangan, menggelapkan oleh seseorang yang memimpin atau bekerja dalam kapasitas apapun dalam suatu badan di sektor swasta atas suatu kekayaan, danadana pribadi atau sekuritas atau segala sesuatu yang bernilai yang dipercayakan kepadanya karena kedudukannya (Pasal 22 United Nations Convention Against Corruption).

Kesembilan, laundering of proceeds of crime atau pencucian hasil kejahatan yaitu tindakan dengan sengaja mengkonversi atau mentransfer kekayaan padahal diketahuinya bahwa kekayaan tersebut merupakan hasil kejahatan dengan maksud untuk menyembunyikan atau menyamarkan asalusul harta kekayaan itu atau membantu seseorang yang terlibat dalam melakukan kejahatan asal untuk menghindari akibat hukum dari tindakannya. Penyembunyian atau penyamaran sifat, sumber, lokasi, kedudukan, pergerakan atau kepemilikan dari atau hak-hak yang sesungguhnya berkenaan dengan kekayaan, mengetahui kekayaan tersebut merupakan hasil kejahatan (Pasal 23 United Nations Convention Against Corruption).

Kesepuluh, concealment atau penyembunyian yaitu tindakan dengan sengaja, setelah dilakukannya salah satu dari kejahatan-kejahatan yang ditetapkan menurut konvensi ini, tanpa turut serta dalam kejahatan-kejahatan tersebut (Pasal 24 United Nations Convention Against Corruption).

Kesebelas, obstruction of justice atau perbuatan menghalang-halangi proses pengadilan yaitu tindakan dengan sengaja menggunakan kekuatan fisik, ancaman atau intimidasi atau janji yang menawarkan atau memberikan suatu keuntungan yang tidak wajar untuk mendorong diberikannya kesaksian palsu atau untuk turut campur dalam pemberian kesaksian atau dalam pengajuan bukti-bukti dalam suatu persidangan berkenaan dengan kejahatankejahatan yang ditetapkan dalam konvensi ini. Demikian pula tindakan penggunaan kekuatan fisik, ancaman atau intimidasi untuk turut campur tangan dalam pelaksanaan tugas-tugas resmi seorang hakim atau seorang pejabat penegak hukum dalam hubungannya dengan kejahatankejahatan yang ditetapkan dalam konvensi ini (Pasal 25 United Nations Convention Against Corruption).

Dari kesebelas tindakan yang dikriminalisasikan dalam UNCAC, ada yang bersifat mandatory offences dan ada yang bersifat non-mandatoty offences. Kedua sifat ini tidak terlepas dari kesepakatan negaranegara peserta dalam konvensi tersebut. Jika suatu tindakan yang dikriminalisasikan bersifat mandatory berarti ada kesepakatan seluruh peserta konvensi untuk mengatur tindakan tersebut dalam undang-undang nasionalnya sehingga menimbulkan kewajiban dari state party. Sebaliknya, jika suatu tindakan bersifat non-mandatory berarti tidak ada kesepakatan di antara para peserta konvensi untuk menyatakan tindakan tersebut sebagai kriminal (Mochtar, 2018).

Ada 5 tindakan yang dikriminalisasikan dalam UNCAC yang bersifat mandatory offences. Masing-masing adalah : bribery of national public officials; bribery of foreign public officials and officials of public international organizations ; embezzlement, misappropriation or other diversion of property by a public official ; laundering of proceeds of crime dan obstruction of justice. Sedangkan 6 tindakan lainnya yang bersifat non-mandatory offences adalah : trading in influence ; abuse of function; illicit enrichment; bribery in the private sector ; emblezzement of property in the private sector dan concealment. 
Perumusan tindakan-tindakan yang dikriminalisasi dalam suatu konvensi internasional sebagaimana juga yang terdapat dalam UNCAC memiliki tiga karakter tersendiri. Pertama, perumusan tindakan yang dikriminalisasikan saling tumpang tindih antara satu dengan yang lain. Kedua, sebagai konsekuensi dari yang pertama, unsur-unsur tindakan yang dikriminalisasikan menjadi tidak jelas. Tegasnya, perumusan yang demikian tidak memenuhi syarat lex certa sebagai hal yang prinsip dalam asas legalitas. Lex certa atau nullum crimen, nula poena, sine lege certa berarti tidak ada perbuatan pidana, tidak ada pidana tanpa undang-undang yang jelas merupakan salah satu syarat yang fundamental dari asas legalitas. Ketiga, perumusan tindakan-tindakan yang dikriminalisasikan tidak diikuti oleh suatu sanksi pidana yang tegas. Karakteristik yang demikian bukanlah tanpa alasan. Hal ini dimaksud agar pelaku kejahatan internasional tidak lolos dari jeratan hukum (Hiariej, 2016).

Korupsi di sektor swasta merupakan non-mandatory offences. Artinya, tidak ada kewajiban dari negara-negara peserta konvensi untuk memasukkan ketentuan tersebut ke dalam hukum nasional negaranya. Secara lengkap ketentuan korupsi di sektor swasta dalam Pasal 21 ayat (1) konvensi tersebut berbunyi, "Setiap orang yang menjanjikan, menawarkan atau memberikan secara langsung maupun tidak langsung, keuntungan yang tidak semestinya kepada seseorang yang memimpin atau bekerja di sektor swasta, baik untuk dirinya sendiri ataupun orang lain dengan maksud agar orang tersebut melakukan atau tidak melakukan sesuatu yang bertentangan dengan tugas dan kewajibannya yang dapat merugikan kegiatan perekonomian atau perdagangan".

Pasal 21 ayat (2) menyatakan, "setiap orang yang memimpin atau bekerja di sektor swasta meminta, atau menerima secara langsung maupun tidak langsung, keuntungan yang tidak semestinya dari seseorang, baik untuk dirinya sendiri ataupun orang lain dengan maksud agar melakukan atau tidak melakukan sesuatu yang bertentangan dengan tugas dan kewajibannya yang dapat merugikan kegiatan perekonomian atau perdagangan."

Berdasarkan pasal tersebut, Pasal 21 ayat (1) diperuntukkan bagi pesuap aktif, sedangkan ayat (2) diperuntukkan bagi pesuap pasif. Adapun unsur-unsur yang harus dibuktikan dari pasal a quo adalah: 1) setiap orang; 2) menjanjikan, menawarkan atau memberi keuntungan yang tidak semestinya langsung maupun tidak langsung; 3) orang yang memimpin atau bekerja di sektor swasta baik untuk dirinya sendiri maupun orang lain; 4) dengan maksud. Dalam hal ini adalah kesengajaan sebagai maksud seperti yang telah diutarakan di atas. 5) orang yang dijanjikan, ditawarkan atau menerima melakukan atau tidak melakukan sesuatu yang bertentangan dengan tugas dan kewajibannya; 6) dapat merugikan kegiatan perekonomian atau perdagangan.

Selanjutnya adalah penggelapan di sektor swasta yang dikualifikasikan sebagai tindak pidana korupsi berdasarkan Pasal 22 UNCAC, "Setiap orang yang memimpin atau bekerja di sektor swasta dengan sengaja menggelapkan kekayaan atau keuangan atau sekuritas atau segala sesuatu yang bernilai yang dipercayakan kepadanya karena kedudukannya yang dapat merugikan kegiatan perkonomian atau perdagangan." Konstruksi pasal yang demikian adalah untuk melindungi kekayaan sektor swasta dari perilaku koruptif oleh orang yang berkerja di dalamnya. Adapun unsur-unsur pasal a quo: 1) Setiap orang yang memimpin atau bekerja di sektor swasta; 2) menggelapkan kekayaan atau keuangan atau sekuritas atau segala sesuatu yang bernilai; 3) yang dipercayakan kepadanya karena kedudukannya; 4) yang dapat merugikan kegiatan perekonomian atau perdagangan.

Kendatipun korupsi di sektor swasta bukan merupakan kewajiban setiap negara peserta untuk memasukkannya dalam hukum nasional negaranya namun untuk 
konteks Indonesia, ketentuan tersebut harus dimasukkan dalam revisi undang-undang pemberantasan tindak pidana korupsi. Pengaturan dalam undang-undang pemberantasan tindak pidana korupsi terkait korupsi di sektor swasta meliputi dua hal. Pertama, penyuapan di sektor swasta baik penyuapan aktif maupun penyuapan pasif. Kedua, penggelapan di sektor swasta.

Pengaturan ini sangatlah mendesak dengan mengingat beberapa hal. Pertama, hampir 75 persen kasus korupsi di Indonesia berada pada sektor pengadaan barang dan jasa. Kedua, pengadaan barang dan jasa selalu melibatkan pihak swasta. Ketiga, nilai nominal yang dikorupsi sangat fantastik yang berpengaruh signifikan terhadap keuangan dan perekonomian negara. Keempat, pihak swasta acapkali melibatkan diri dalam kasus korupsi dengan modus operandi yang canggih untuk mengelabuhi hasil kejahatan korupsi.

Pengaturan korupsi di sektor swasta di masa mendatang harus disempurnakan dengan pertanggungjawaban pidana korporasi dalam tindak pidana korupsi. Hal ini agar mempermudah dan memperlancar aparat penegak hukum untuk mejerat korupsi yang dilakukan oleh korporasi. Terlebih dalam kontek Indonesia, persoalan tersisa yang masih menimbulkan perdebatan adalah korupsi yang dilakukan oleh korporasi yang berbentuk Badan Usaha Milik Negara (BUMN).

\section{Pertanggungjawaban Korporasi}

Pidana

Apakah korporasi dapat dimintakan pertanggungjawaban adalah suatu pertanyaan mendasar yang sudah lama mewacana. Demikian pula ketika berbicara mengenai pertanggungjawaban pidana korporasi yang telah menjadi perdebatan sejak awal abad 19. Namun, sampai dengan abad milenial ini, ada beberapa negara yang secara tegas tidak menganut pertanggungjawaban korporasi dalam hukum pidananya seperti Jerman, Italia, Yunani, Portugal dan Spanyol. Padahal, negara-negara tersebut memiliki sistem hukum yang sama dengan kita yakni civil law system atau sistem Eropa continental.

Negara-negara tersebut berpegang teguh pada dua doktrin yang dikemukakan oleh von Savigny dan Malblanc. Pertama, universitas delinquere non potest (korporasi tidak dapat dipidana) dan kedua, societies delinquere non potest (korporasi tidak mungkin melakukan tindak pidana) (Muladi dan Dwija Priyanto, 2010). Pandangan Savigny dan Malblanc tidak terlepas dari pandangan common law bahwa korporasi tidak dapat dituntut. Di negara-negara tersebut, pertanggungjawaban korporasi hanya dikenal dalam lapangan hukum perdata dan hukum administrasi (Podgor, 1993). Dalam konteks hukum pidana di Indonesia yang juga mengenal pertanggungjawaban korporasi, teori-teori yang digunakan sebagian besar adalah teori identifikasi, teori agregasi dan teori vicarious liability. Perdebatan pertanggungjawaban korporasi juga tergantung pada konsep mens rea. Dalam konteks perkembangan hukum pada negaranegara eropa, konsep ini didasarkan pada "act does not make a person guilty, unless the mind is legally blamed" (Lanius, 2019) dimana perbuatan dan kehendak harus samasama bersalah. Terdapat dua syarat yang harus dipenuhi, yakni adanya perbuatan salah atau dikenal dengan actus reus dan kehendak yang salah atau mens rea (Lanius, 2019).

Pertanyaan lebih lanjut, undang-undang pemberantasan tindak pidana korupsi kita mengikuti teori yang mana? Pasal 20 ayat (1) dan ayat (2) UU a quo secara eksplisit menyatakan: (1) Dalam hal tindak pidana korupsi dilakukan oleh atau atas nama suatu korporasi, maka tuntutan dan penjatuhan pidana dapat dilakukan terhadap korporasi dan atau pengurusnya. (2) Tindak pidana korupsi dilakukan oleh korporasi apabila tindak pidana tersebut dilakukan oleh orang-orang baik berdasarkan hubungan kerja maupun berdasarkan hubungan lain, bertindak dalam lingkungan korporasi tersebut baik sendiri maupun bersamasama. Ketentuan tersebut sepintas kilas, 
seolah-olah antara ayat (1) dan ayat (2) pasal a quo berhubungan. Namun, jika dikaji lebih mendalam, antara ayat (1) dan ayat (2) menggunakan dua teori yang berbeda. Pasal 20 ayat (1) menggunakan teori identifikasi. Di sini yang didakwa dan dituntut adalah pengurus untuk dan atas nama korporasi sekaligus untuk dan atas nama individu. Sedangkan ayat (2) menggunakan teori agregasi. Artinya, yang didakwa dan dituntut adalah korporasi.

Ketentuan lebih lanjut perihal pertanggungjawaban pidana korporasi diatur dalam Peraturan Mahkamah Agung Nomor 13 tahun 2016. Berdasarkan Peraturan Mahkamah Agung, ada 3 kemungkinan tanggung jawab pidana oleh korporasi. Pertama, jika kejahatan memberikan manfaat atau keuntungan atau memenuhi kepentingan korporasi. Kedua, jika korporasi membiarkan tindak pidana. Ketiga, jika korporasi tidak melakukan langkah-langkah yang diperlukan agar tidak terjadi tindak pidana, termasuk dampak besar setelah tindak pidana tersebut terjadi. Peraturan Mahkamah Agung tersebut perlu diapresiasi sebagai guidance aparat penegak hukum untuk melakukan penuntutan terhadap korporasi. Adapun kelemahan mendasar pada Peraturan Mahkamah Agung tersebut adalah pada kemungkinan kedua dan ketiga yang menghendaki crime by omission pada rumusan delik korupsi. Tegasnya, jika rumusan delik korupsi tidak mencantumkan secara eksplisit perbuatan negatif dalam rumusan delik, maka kemungkinan kedua dan ketiga tidak dapat dijerat terhadap korporasi.

Pertanyaan lebih lanjut, apakah terhadap suatu korporasi penuntutan dapat dilakukan terhadap pengurus sekaligus terhadap korporasi? Secara tegas: Ya. Artinya, Pasal 20 ayat (1) undang-undang $a$ quo dapat diterapkan kepada pengurus, sedangkan Pasal 20 ayat (2) UU Tipikor dapat diterapkan terhadap korporasi. Perkaranya pun dapat dipisah, tergantung tingkat kerumitan dan penilaian subjektif penuntut umum. Hanya saja yang perlu diperhatikan adalah putusan hakim. Jika putusan hakim telah menghukum pengurus dan juga korporasi, padahal penuntutan hanya dilakukan terhadap pengurus, maka korporasi tidak dapat lagi dituntut karena asas nebis in idem (seseorang tidak dapat dituntut lebih dari satu kali di depan pengadilan dengan perkara yang sama). Kalaupun korporasi tetap dituntut secara terpisah, padahal telah ada putusan yang memidana pengurus dan korporasi, maka putusan bersalah terhadap korporasi tidak diikuti oleh pemidanaan. Pada titik yang paling ekstrim, jika ada pemidanaan maka pemidanaan terdahulu harus tetap diperhitungkan sebagaimana dimaksud dalam Pasal 71 KUHP sebagai perbuatan pidana tertinggal.

Hal lain yang perlu diperhatikan Polri, Kejaksaan maupun KPK untuk menjerat korporasi adalah dengan meneliti terlebih dulu kejahatan yang terjadi, apakah crimes for corporation, crimes against corporation ataukah criminal corporations (Ferguson Jr, 2010). Crimes for corporation diartikan sebagai korporasi yang melakukan kejahatan untuk kepentingan dan keuntungan korporasi. Sebagai misal, korporasi yang acapkali melakukan penyuapan miliaran rupiah kepada penyelenggara negara dalam beberapa kasus. Dalam konteks ini, sulit dikatakan kalau korporasi tidak terlibat secara terstruktur dan sistematis.

Jika terjadi demikian, maka Pasal 20 ayat (1) dan ayat (2) dapat diterapkan terhadap korporasi. Lain halnya jika yang terjadi adalah crimes against corporation atau juga disebut employes crimes. Di sini kejahatan dilakukan oleh karyawan terhadap korporasi. Tegasnya, korporasi adalah korban. Dalam konteks yang demikian, korporasi tidak dapat dimintakan pertanggungjawaban pidana. Lain halnya pula jika yang terjadi adalah criminal corporations yaitu korporasi yang dibentuk dengan sengaja dan dikendalikan untuk melakukan kejahatan (Setiyono, 2005). Dalam beberapa kasus korupsi di Indonesia, ada beberapa korporasi yang sengaja dibentuk untuk menampung kickbacks atau uang suap dari sejumlah pembangunan mega 
proyek. Dalam konteks ini, terhadap korporasi tidak hanya diterapkan Pasal 20 ayat (1) dan ayat (2) undang-undang a quo, tetapi juga harus dibubarkan.

Hal terakhir yang penting diperhatikan oleh Polri, Kejaksaan dan Komisi Pemberantasan Korupsi ketika akan menjerat korporasi dalam konteks crimes for corporation adalah memitigasi dua persoalan penting. Pertama, sesaat korporasi dinyatakan sebagai tersangka serta merta berbagai pihak yang sedang atau akan melakukan transaksi bisnis dengan korporasi tersebut akan berhenti seketika. Sebab pandangan masyarakat kita, penetapan tersangka telah memberi stigma bersalah dan mengesampingkan presumption of innocent. Pihak mana yang mau atau melanjutkan transaksi dengan korporasi yang dinyatakan sebagai tersangka? Belum lagi, jika semua rekening korporasi diblokir atas perintah aparat penegak hukum. Secara mutatis mutandis income korporasi akan menurun padahal penjatuhan pidana maksimal hanya berupa denda dan uang pengganti. Kedua, konsekuensi logis dari yang pertama, income perusahan akan menurun drastis, bahkan korporasi tidak dapat menjalankan usahanya. Dalam konteks ini, bagaimana dengan nasib ratusan atau mungkin ribuan karyawan yang berada di ambang pemutusan hubungan kerja? Sebab, bagaimanapun kejamnya hukum pidana, pemidanaan harus tetap mendatangkan manfaat, tidak hanya bagi korban, namun juga terhadap pelaku dalam rangka fungsi rehabilitatif dan yang terdampak dari pemidanaan itu sendiri.

Hal lain yang perlu dibahas pada akhir tulisan ini adalah korupsi BUMN. Isu ini menjadi menarik bila dihubungkan dengan korupsi di sektor swasta dan pertanggungjawaban pidana koporasi. Ada dua isu pokok yang sampai saat ini belum ada titik temu di kalangan akademisi. Pertama, apakah kekayaan BUMN adalah kekayaan negara ataukah kekayaan BUMN merupakan kekayaan terpisah dari kekayaan negara? Jika kekayaan BUMN merupakan kekayaan terpisah, maka BUMN tidak ada bedanya dengan swasta. Kedua, apakah negara dapat dimintakan pertanggungjawaban pidana dalam konteks pertanggungjawaban korporasi.

Jawaban atas kedua isu tersebut membawa dampak signifikan terhadap penindakan hukum atas suatu tindak pidana korupsi yang dididuga dilakukan oleh BUMN. Bagi akademisi yang mendalami hukum bisnis maupun hukum perdata, berpendapat bahwa kekayaan BUMN adalah kekayaan yang terpisah dari kekayaan negara. Hal ini secara tegas dinyatakan dalam undang-undang BUMN. Sedangkan para akademisi hukum pidana berpendapat bahwa kekayaan BUMN adalah kekayaan negara yang secara mutatis mutandis merupakan keuangan negara. Hal ini dinyatakan secara eksplisit dalam penjelasan undang-undang pemberantasan tindak pidana korupsi.

Jika kekayaan BUMN merupakan kekayaan terpisah dari kekayaan negara, maka bila ada tindak pidana yang merugikan keuangan BUMN tidaklah dapat dikatakan tindak pidana korupsi, namun merupakan tindak pidana umum lainnya. Dalam konteks ini yang terjadi adalah crimes against corporation atau employes crimes. Di sini kejahatan dilakukan oleh karyawan terhadap korporasi. Tegasnya, korporasi adalah korban. Demikian pula jika suatu tindak pidana menguntungkan BUMN, maka hanya merupakan tindak pidana umum sebagai crimes for corporation. Lain halnya jika kekayaan BUMN merupakan kekayaan negara. Jika terjadi tindak pidana yang merugikan BUMN, maka dapat dikualifikasikan sebagai tindak pidana korupsi. Sebaliknya, jika tindak pidana tersebut menguntungkan BUMN, tidak dapat dikatakan sebagai tindak pidana korupsi.

Perdebatan ini akan membawa konsekuensi bagi pertanggungjawaban pidana korporasi dalam konteks tindak pidana korupsi. Jika kekayaan BUMN adalah kekayaan terpisah, maka kejahatan yang dilakukan oleh BUMN sebagai korporasi dapat dimintakan pertanggungjawaban. Artinya, BUMN tersebut dapat dijatuhi pidana berupa denda 
dan pidana tambahan berupa uang pengganti. Sebaliknya, jika kekayaan BUMN adalah kekayaan negara, maka jika terjadi tindak pidana yang menguntungkan BUMN, selain bukan tindak pidana korupsi, BUMN sebagai korporasi tidak dapat dimintakan pertanggungjawaban pidana. Tidaklah mungkin negara yang melakukan penuntutan secara pidana menuntut dirinya sendiri untuk dimintakan pertanggungjawaban pidana.

Perihal pertanggungjawaban pidana lembaga negara sebagai korporasi pernah menimbulkan perdebatan di Belanda. Dalam kasus peledakan kembang api di Enschede tahun 2002 yang melibatkan pemerintah kota, penuntutan pidana terhadap negara ditolak oleh pengadilan. Perkembangan selanjutnya, dalam kasus The Zederpollution pada tahun 2007, pengadilan menyatakan penuntutan terhadap pemerintah kota secara pidana diterima dan dinyatakan bersalah. Di Perancis, dalam KUHP tahun 1994, pertanggungjawaban pidana negara dikecualikan (Muladi dan Diah Sulistyani RS, 2015). Jika terjadi suatu tindak pidana yang melibatkan lembaga pemerintah, maka yang bertanggung jawab secara pidana adalah orang yang menduduki jabatan tersebut. Penulis sendiri berpendapat bahwa negara tidaklah dapat dimintakan pertanggungjawaban secara pidana, sebab penuntutan yang dilakukan oleh jaksa penuntut umum adalah untuk dan atas nama negara sehingga tidaklah mungkin negara untuk dan atas nama negara menuntut pertanggungjawaban pidana dari negara sendiri.

Perdebatan terkait kedua hal ini akan berakhir, jika undang-undang pemberantasan tindak pidana korupsi disesuaikan dengan UNCAC yang telah diratifikasi dengan Undang-Undang Nomor 6 Tahun 2007 dengan memasukkan korupsi di sektor swasta. Saat ini, korupsi di sektor swasta hanya merupakan perbuatan yang dilarang sebagaimana terdapat dalam Pasal 21 UNCAC tetapi bukan merupakan perbuatan pidana. Sebab, syarat dari perbuatan pidana adalah perbuatan yang dilarang dalam undang-undang disertai ancaman pidana bagi yang melanggar larangan atau tidak mentaati perintah.

Terakhir, berkaitan dengan penjatuhan pidana terhadap korporasi (termasuk BUMN) bila mana melakukan suatu tindak pidana. Seperti yang telah diutarakan di atas, sanksi pidana yang dapat dijatuhkan terhadap korporasi hanyalah denda, termasuk pembayaran ganti rugi. Pertanyaan lebih lanjut, apa yang terjadi jika korporasi tidak dapat membayar denda atau ganti rugi? Dalam konteks ini berlaku postulat qui non habet ia aere luat in corpore, ne quis peccetur impune. Artinya, jika korporasi tidak bisa membayar denda atau kerugian, maka kewajiban itu dilimpahkan kepada individunya, untuk mencegah impunitas. Di sini, kekayaan pribadi pengurus korporasi tersebut yang digunakan untuk membayar denda, termasuk ganti rugi.

\section{Simpulan dan Saran}

Berdasarkan uraian dalam pembahasan sebelumnya, penulis dapat merumuskan simpulan bahwa pengaturan korupsi di sektor swasta sebagaimana yang terdapat dalam UNCAC barulah sebatas perbuatan yang dilarang namun belum merupakan perbuatan pidana karena tidak terdapat sanksi pidana di dalamnya. Pertanggungjawaban pidana korporasi dalam tindak pidana korupsi sebagaimana yang diatur dalam undang-undang menganut teori identifikasi dan teori agregasi, namun pengaturannya tidak jelas sehingga bisa menimbulkan multitafsir.

Adapun saran yang dapat diusulkan kepada Dewan Perwakilan Rakyat dan Presiden sebagai pembentuk undang-undang adalah sebagai berikut: Pertama, UndangUndang Pemberantasan Tindak Pidana Korupsi harus sesegera mungkin disesuaikan dengan UNCAC dan perlu memasukkan korupsi di sektor swasta yang meliputi penyuapan dan penggelapan. Hal ini mengingat modus operandi kasus korupsi di tanah air selalu melibatkan pihak swasta terutama korupsi di sektor pengadaan barang dan jasa. Kedua, pengaturan 
pertanggungjawaban pidana korupsi dalam Undang-Undang Pemberantasan Tindak Pidana Korupsi harus diperbaiki sehingga menjadi jelas dan tidak ada keraguan oleh penegak hukum dalam konteks penegakkan hukum.

\section{DAFTAR PUSTAKA}

Beirne, P. and J. M. (1995). Criminology (2nd ed.). Hardcourt College Publisher, hlm.295 - 297.

Emmanuel, M. ; L. Q. (2019). The Impact of Corruption on Government Public Services Quality, Justice and Cost of Business Regulations in Developing World. International Journal of Innovation and Research in Educational Sciences, 6(1), 27-28.

Ferguson Jr, J. (2010). White - Collor Crime. Chelsea House Publisher.

He Zengke. (2003). Research in the Issues of Corruption and Combationg Corruption during Chinese Transition. Comparative Economic \& Social Systems, 1(1), 1929.

Hiariej, E. O. . (2016). Prinsip-Prinsip Hukum Pidana. (C. A. Pustaka, Ed.). Yogyakarta.

Isra, S. dan E. O. . H. (2009). Perspektif Hukum Pemberantasan Korupsi Di Indonesia. In Korupsi Mengorupsi
Indonesia: Sebab, Akibat dan Prospek Pemberantasan (p. 565). Jakarta: Gramedia Pustaka Utama.

Lanius, D. (2019). Strategic Indeterminacy in the Law. Oxford: Oxford University Press.

Liu, A. (2016). Literature Review on the Definition of Corruption and Factors Affecting the Risk of Corruption. Open Journal of Social Sciences, 4(6), 172.

Mochtar, Z. A. dan E. O. . H. (2018). Menjerat Korupsi Partai Politik. Yogyakarta: Genta Publishing.

Muladi dan Diah Sulistyani RS. (2015). Pertanggungjawaban Pidana Korporasi (Corporate Criminal Responbility). Bandung: Alumni.

Muladi dan Dwija Priyanto. (2010). Pertanggungjawaban Pidana Korporasi. (K. P. M. Group, Ed.). Jakarta.

Pinto, A. ; M. E. (2003). Corporate Criminal Liability. London: Sweet \& Maxwel.

Podgor, E. S. (1993). White Collor Crime. ST Paul Minn: West Publishing Co.

Setiyono. (2005). Kejahatan Korporasi; Analisis Viktimologi Dan Pertanggungjawaban Korporasi Dalam Hukum Pidana Indonesia Malang. Malang: Bayumedia. 